\title{
Differentiation of normal and cancer cells induced by sulfhydryl reduction: biochemical and molecular mechanisms
}

\author{
T Parasassi ${ }^{\star, 1}$, R Brunelli ${ }^{1,2}$, L Bracci-Laudiero ${ }^{1}$, G Greco ${ }^{1}$, \\ AC Gustafsson ${ }^{3}$, EK Krasnowska ${ }^{1}$, J Lundeberg ${ }^{3}$, \\ T Lundeberg ${ }^{4}$, E Pittaluga ${ }^{1}$, MC Romano ${ }^{5}$, and A Serafino ${ }^{1}$ \\ ${ }^{1}$ Istituto di Neurobiologia e Medicina Molecolare, CNR, Viale Marx 15-43, 00137 \\ Roma, Italy \\ 2 Dipartimento di Scienze Ginecologiche, Perinatologia e Puericultura, \\ Universita' di Roma La Sapienza, Viale del Policlinico 155, Roma, Italy \\ 3 Department of Biotechnology,KTH, Royal Institute of Technology, AlbaNova \\ University Center, Roslagstullsbacken 21, Stockholm 10691 , Sweden \\ ${ }^{4}$ Rehabilitation Medicine, Karolinska University Hospital, Stockholm 11776 , \\ Sweden \\ ${ }^{5}$ Associazione Italiana Iniziativa Medicina Sociale, Corso Trieste 16, Roma \\ 00185 , Italy \\ * Corresponding author: T Parasassi, Istituto di Neurobiologia e Medicina \\ Molecolare, CNR, Viale Marx 15-43, Roma 00137 , Italy. \\ Tel: + 39-06-86090316; Fax: + 39-06-86090370; \\ E-mail: t.parasassi@inmm.cnr.it
}

Received 10.1.05; revised 21.3.05; accepted 05.4.05; published online 27.5.05 Edited by A Finnazzi-Agro'

\begin{abstract}
We examined the morphological, biochemical and molecular outcome of a nonspecific sulfhydryl reduction in cells, obtained by supplementation of $\mathrm{N}$-acetyl-L-cysteine (NAC) in a $0.1-10 \mathrm{mM}$ concentration range. In human normal primary keratinocytes and in colon and ovary carcinoma cells we obtained evidences for: (i) a dose-dependent inhibition of proliferation without toxicity or apoptosis; (ii) a transition from a proliferative mesenchymal morphology to cell-specific differentiated structures; (iii) a noticeable increase in cell-cell and cell-substratum junctions; (iv) a relocation of the oncogenic $\beta$-catenin at the cell-cell junctions; (v) inhibition of microtubules aggregation; (vi) upregulation of differentiation-related genes including p53, heat shock protein 27 gene, $\mathrm{N}$-myc downstream-regulated gene 1, E-cadherin, and downregulation of cyclooxygenase-2; (vii) inhibition of c-Src tyrosine kinase. In conclusion, a thiol reduction devoid of toxicity as that operated by NAC apparently leads to terminal differentiation of normal and cancer cells through a pleiade of converging mechanisms, many of which are targets of the recently developed differentiation therapy.

Cell Death and Differentiation (2005) 12, 1285-1296.

doi:10.1038/sj.cdd.4401663; published online 27 May 2005
\end{abstract}

Keywords: colon carcinoma; cyclooxygenase-2; junctions; ovary carcinoma; proliferation; c-Src

Abbreviations: HSP27, heat shock protein 27 gene; NAC, $N$ acetyl-L-cysteine; NHEK, normal human epidermal keratinocytes;
NDRG1, N-myc downstream-regulated gene 1; NSAIDs, nonsteroidal anti-inflammatory drugs

\section{Introduction}

Molecular and biochemical evidences attribute several regulatory functions to the redox state of thiol groups. Modulation of protein activity by disulfide bond formation represents a universal and common mechanism to adopt a fast and efficient turn on-off of cellular signaling. ${ }^{1}$ In particular, protein tyrosine phosphatases play a pivotal role in the control of cell cycle and differentiation, and were reported to be regulated through the redox state of their cysteine $-\mathrm{SH}$ residues. ${ }^{2,3}$ Also protein tyrosine kinases have an essential role in the control of cell proliferation and differentiation. For three of them, Yes, Fyn and c-Src, a redox regulation has been recently reported ${ }^{4,5}$ and particularly for $\mathrm{c}-\mathrm{Src}$, it apparently implies a reversible change in the redox state of a group of four cysteine residues close to the catalytic site. ${ }^{4-7}$

The activity of transcription factors can also be modulated through thiol interactions: Binding of transcription factors to DNA may be sensitive to the redox state of sulfhydryl residues or to the presence of specific soluble thiols. ${ }^{1,8,9}$

The study of the effect of sulfhydryl reduction is therefore an extremely attractive issue that we pursued by supplementing $\mathrm{N}$-acetyl-L-cysteine (NAC) to different cell types, two human carcinoma lines and primary human epidermal keratinocytes. We found for the first time that this reductant treatment is able to induce cell differentiation through the modulation of several mechanisms, with modalities that depend on the cell type. Besides a dose-dependent inhibition of proliferation in the absence of both toxicity and apoptosis, our results show morphological, biochemical and molecular changes related to terminal differentiation. Following the current knowledge on the differentiation process, some of the observed changes can also represent the actual driving mechanism for differentiation.

The results obtained on normal primary cells suggest that the presented redox-driven mechanisms pertain to the general cell physiology and that the grade of cell malignancy could be related to the maintenance of the ability to respond to some of the outlined signals.

\section{Results}

\section{Growth inhibition}

Different NAC concentrations were tested on two human colon and ovary carcinoma cell lines, Caco-2 and OVCAR3, respectively, and primary normal human keratinocytes (NHEK). The results show that a decrease or a complete block of $\left[{ }^{3} \mathrm{H}\right]$ thymidine incorporation could be obtained by using effective NAC concentrations that were specific for each 
cell type (Figure 1a). The proliferation of Caco-2 cells rapidly decreased after a double supplementation of NAC, at $24 \mathrm{~h}$ interval, reaching a block of about $95 \%$ at $10 \mathrm{mM}$, while a single supplementation with $5 \mathrm{mM}$ NAC resulted in a block of about $85 \%$. The OVCAR3 proliferation instead, was reduced to about $40 \%$ after two supplementations with $10 \mathrm{mM} \mathrm{NAC \text {. }}$ The NHEK were the most sensitive to NAC treatment, being almost completely blocked by a single supplementation of 2 mM NAC. When we also tested NAC concentrations lower than $0.5 \mathrm{mM}$, the cell proliferation was slightly increased, suggesting a trophic effect of NAC at these low concentrations. NAC supplementation did not alter cell viability, as tested by Trypan blue exclusion method, always between 94 and $96 \%$. In addition, the cytometric analysis of Caco-2 and OVCAR3 cells did not show any evidence of apoptosis after
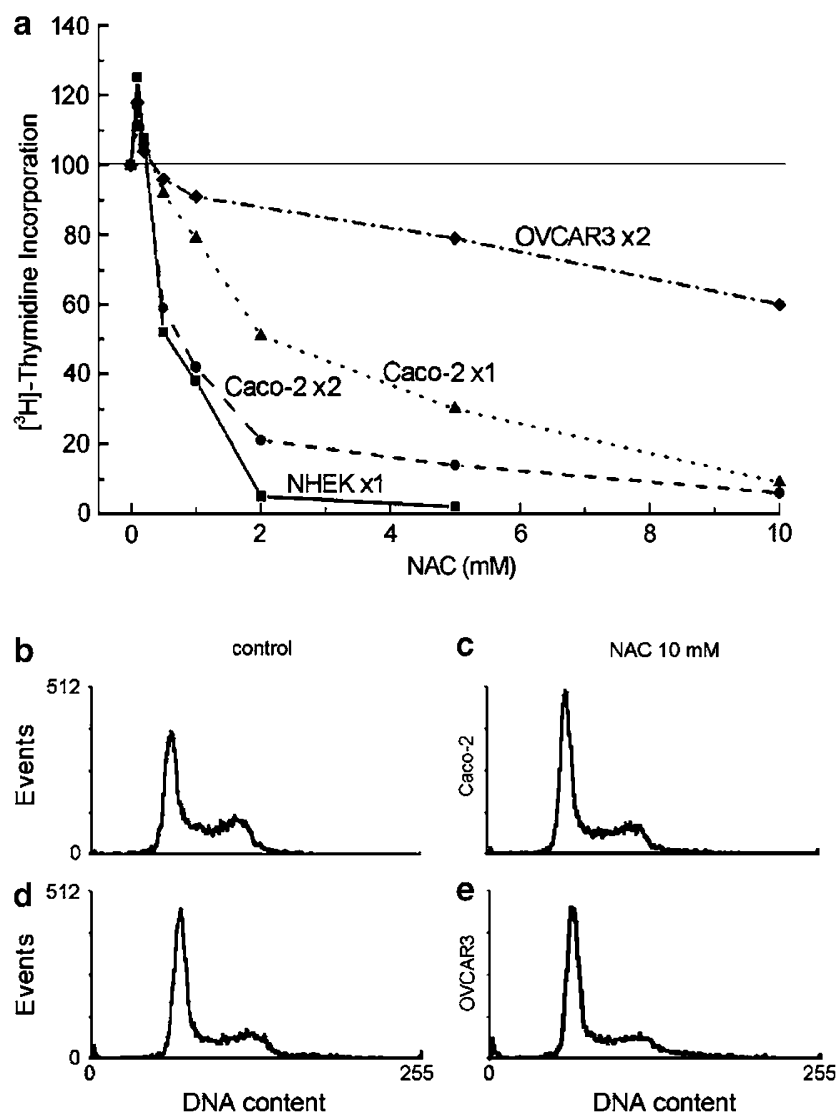

Figure 1 (a) $\left[{ }^{3} \mathrm{H}\right]$ Thymidine incorporation of cells treated with NAC. Data normalized to controls and reported as a function of NAC concentration for a single supplementation to NHEK, for a single ( $\mathrm{x} 1)$ and a double supplementation ( $\mathrm{x} 2$, at $24 \mathrm{~h}$ interval) to Caco-2 and OVCAR3 cells. (b-e): Flow cytometry data of propidium iodide-labeled Caco-2 ( $b$ and $\mathbf{c}$ ) and OVCAR3 ( $\mathbf{d}$ and $\mathbf{e}$ ) cells, controls (b and $\mathbf{d}$ ) and treated with $10 \mathrm{mM}$ NAC (c and e). OVCAR3 cells were treated twice at $24 \mathrm{~h}$ interval supplementation with all tested NAC concentrations, even after two supplementations with $10 \mathrm{mM} \mathrm{NAC}$, at $24 \mathrm{~h}$ interval, as in the case of OVCAR3 cells. In the Figure 1b-e we only report the cytometry data relative to controls and to the highest NAC concentration. The data analysis ${ }^{10}$ also indicated an increase in the relative concentration of cells in the G1 phase, of about 25 and $10 \%$ for Caco-2 and OVCAR3 cells, respectively. This last observation is consistent with all additional evidences of cell differentiation, reported in the following sections.

\section{Morphological changes}

Proliferating Caco-2 cells display an irregular morphology and form several multiple cell layers with scarce microvillous structures and large intercellular space (Figure $2 a$ and $c$ ). A single supplement of $2 \mathrm{mM}$ NAC was given to Caco-2 cells, $24 \mathrm{~h}$ after seeding. Cells were then grown for three more days and analyzed. NAC-treated Caco-2 cells showed: (i) a regular polygonal morphology typical of end-stage differentiated cells; (ii) an increased thickness, about three times than that of controls (Figure 2a, b and k); (iii) a relevant number of brush border microvilli at the cell surface (Figure 2d, e and h); (iv) a well-developed secretory vesicles apparatus in the vicinity of the microvillous structures (Figure $2 \mathrm{~h}-\mathrm{k}$ ); (v) a dramatically reduced intercellular space (arrows in Figure 2d); (vi) the location of the nucleus in the basal portion (Figure $2 \mathrm{~g}$ ), as it is in differentiated cells.

Primary NHEK have a limited life span in culture, of approximately 30 days, with a terminal differentiation achieved at the end of this period, concurrently with the formation of the cornified envelope. During the first passages, proliferating NHEK show a heterogeneous polygonal morphology, with a villous surface, relatively broad intercellular space and multiple cell layers can be observed with increasing cell density (Figure $3 a$ and d). At 3 days after a $2 \mathrm{mM}$ supplementation of NAC, NHEK grew flat in a thin monolayer, with a regular polygonal morphology (Figure $3 \mathrm{~b}$ ) and a smooth surface, losing the fine microvillous structure of proliferating keratinocytes (Figure 3e). We observed a relevant number of cells expelling their nucleus and exfoliating, as in the cornified envelope stage (Figure $3 b, c$ and inset). In addition, NACtreated cells had dramatically reduced intercellular space (Figure 3e).

\section{Increase in cell-cell and cell-substratum adhesions}

NAC-treated Caco-2 showed a remarkable increase in $\beta$ catenin and E-cadherin labeling (Figure 4c-f). As analyzed by the NIH ImageJ software, the integrated fluorescence

Figure 2 Effect of NAC treatment on the morphology of Caco-2 cells. (a-e) Scanning electron micrographs of controls (a and $\mathbf{c})$ and of NAC-treated cells (b, $\mathbf{d}$ and $\mathbf{e})$. Arrows in (d) point to cell-cell junctions. In (e) is a detail of brush border microvilli. $(\mathbf{f}-\mathbf{h})$ : Transmission electron micrographs of control (f) and of NAC-treated cells ( $\mathbf{g}$ and $\mathbf{h})$. Arrowheads in $(\mathbf{g})$ and $(\mathbf{h})$ point to brush border microvilli and open arrows in (h) point to secretory vesicles. (i): Confocal fluorescence micrographs of intracellular secretory vesicles apparatus. Fluorescence intensity of the WGA-TRITC-labeled Golgi apparatus and endoplasmic reticulum in controls (i and top k) and in NAC-treated cells ( $\mathbf{j}$ and bottom $\mathbf{k}$ ). The apical distribution of secretory vesicles is well visualized in the longitudinal sectioning along the $x / z$ plane of images (k) with the intensity color scale on the right. Bars: $25 \mu \mathrm{m}$ in (a, b, i, j); $10 \mu \mathrm{m}$ in (c and $\mathbf{d}) ; 5 \mu \mathrm{m}$ in (e); $1 \mu \mathrm{m}$ in (f, g); $300 \mathrm{~nm}$ in (h) 

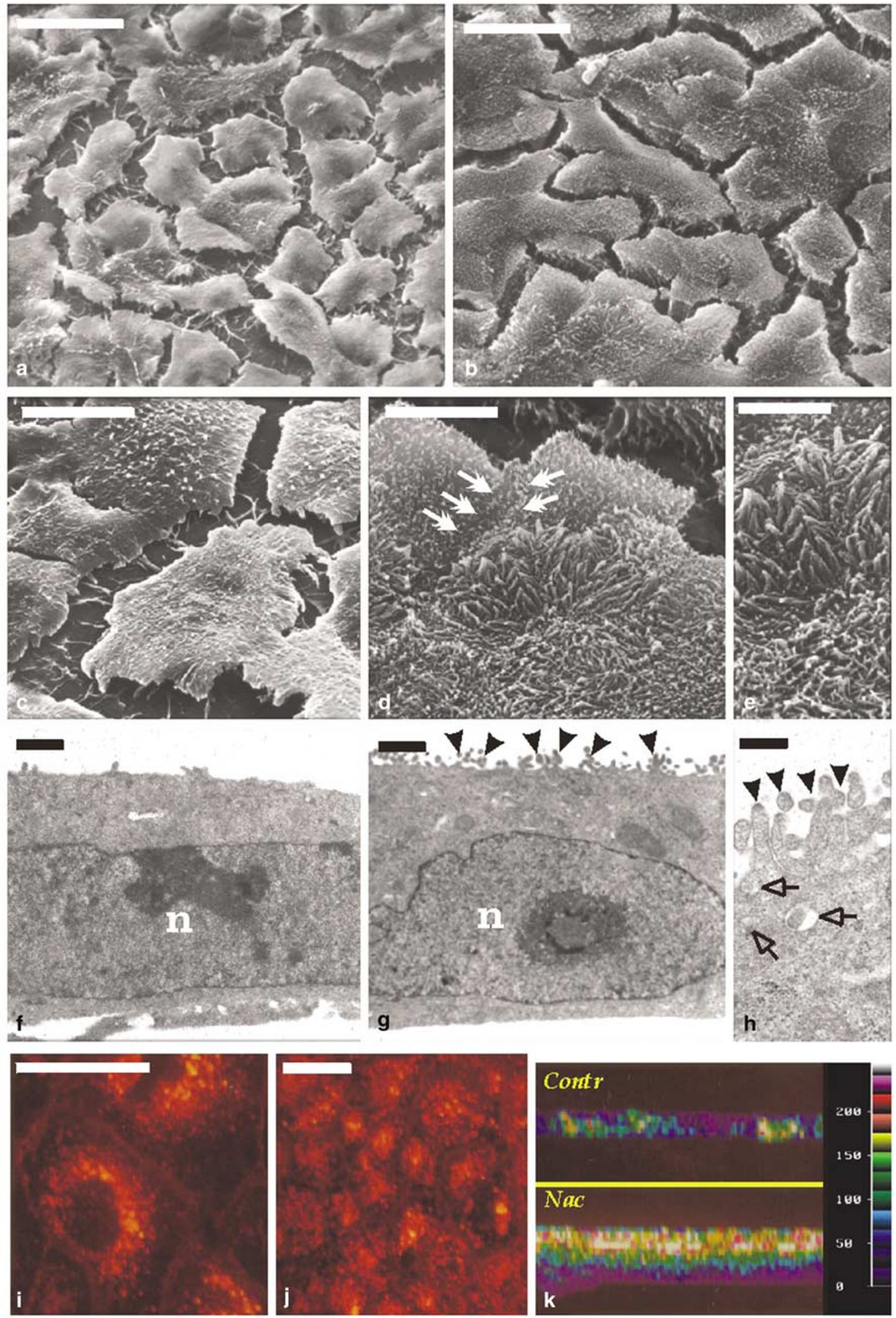

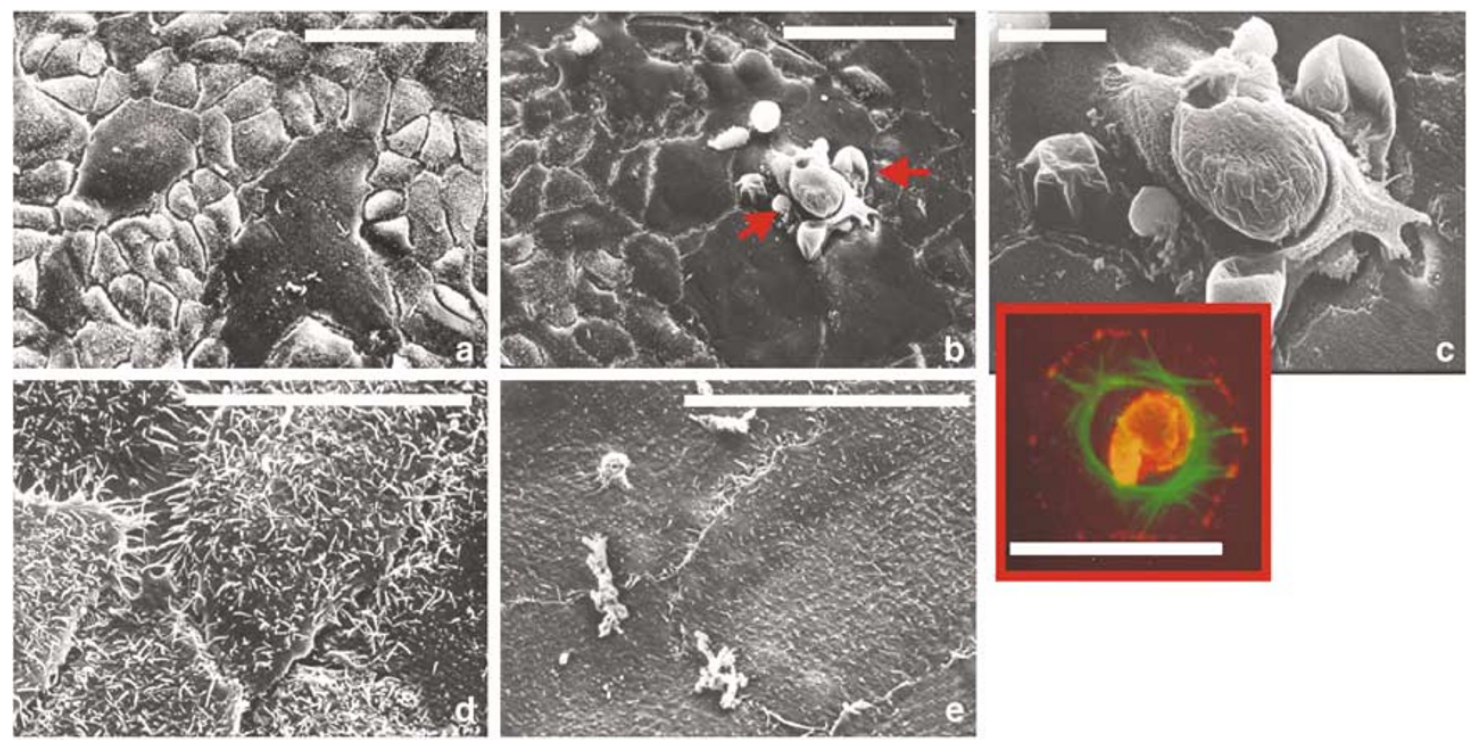

Figure 3 Effect of NAC treatment on NHEK morphology. (a-e) Scanning electron micrographs of controls (a and $\mathbf{d})$ and of NAC-treated cells (b, c and e); arrows in (b) point to a cell showing initial stage of the cornified envelope, detailed in $\mathbf{c}$ at higher magnification. Inset: confocal fluorescence micrograph of an actin-vinculin (green and red, respectively) double-stained cornified cell showing that actin microfilaments participate to the enucleation process. Bars: $100 \mu \mathrm{m}$ in (a and b); $25 \mu \mathrm{m}$ in (c-e) and inset

intensity of $\beta$-catenin and $\mathrm{E}$-cadherin increased of a factor between 7 and 10 in treated versus untreated Caco- 2 cells. The intracellular localization of $\beta$-catenin was also greatly affected by NAC, with redistribution from the nucleus to adherens junctions. Also cell-substratum adhesion plaques increased after NAC treatment, with the formation of several focal adhesions below and around the cell monolayer (Figure $4 \mathrm{~g}$ and $\mathrm{h})$.

After 3 days from a $5 \mathrm{mM}$ NAC treatment, OVCAR3 cells showed clear morphological changes, from large and flat to smaller and regularly polygonal (Figure 4i-I, upper insets), and with the disappearance of $\beta$-catenin labeling from the nucleus while it increased at the level of cell-cell junctions (Figure 4i-I). From the image analysis, in NAC-treated OVCAR3 cells the $\beta$-catenin fluorescence intensity at the junctions increased of a factor of 30 with respect to controls (Figure 4i-I).

Also NHEK treated with NAC $(2 \mathrm{mM})$ showed an increased number of intercellular junctions, with $\beta$-catenin bound to junctions (Figure $4 \mathrm{~m}$ and $\mathrm{n}$ ), and a modified distribution of focal adhesion plaques, as evidenced by vinculin labeling, both below and at the borders of the cell monolayer (Figure 40 and $p)$.

\section{Modification of cell cytoskeleton}

NAC treatment induced a reorganization of cell cytoskeleton both in Caco-2 and in NHEK cells, as evidenced by its fragmentation followed by a rearrangement of the relative location of cytokeratin and actin at early $(24 \mathrm{~h})$ and later times (72 h), respectively. In Caco-2 cells, $24 \mathrm{~h}$ after NAC supplementation, fragmented and curly cytokeratin fibers were observed (Figure 5b). After 3 days, the cytokeratin signal strongly increased (Figure $5 c$ and d) and actin fibers were located in the upper cell portion, sustaining the brush border microvilli (Figure $5 \mathrm{~g}$ and $\mathrm{h}$ ). Untreated control tumor cells showed a random or even opposite location of actin and cytokeratin (Figure 5c). As a consequence and in agreement with increased cell-cell and cell-matrix adhesions shown above, cell motility was dramatically reduced so that the NACtreated culture was constituted of sparse colonies in monolayers instead of cells covering the whole flask, occasionally with multiple layers, as in controls (Figure $5 \mathrm{i}-\mathrm{j}$ ). Residual proliferating cells were present in our samples, as expected in Caco- 2 cells treated with $2 \mathrm{mM}$ NAC (Figure 1a), but we observed that although chromosomes were doubled, for the lack of tubulin polymerization, several cells could not divide and the mitotic spindle could not be formed, so that anomalous prophase features were detected (Figure $5 \mathrm{k}$ and I).

In NHEK, at early times after exposure to NAC, actin fibers showed several stress fibers (Figure 6a and b) and cytokeratin was fragmented and curly (Figure $6 \mathrm{c}$ and $\mathrm{d}$ ). This fragmentation was confirmed by electrophoresis of the whole cytoskeleton extract where we observed more bands than those in the cytoskeleton extracted from control cells (Figure 6i). At 3 days after NAC supplementation, images of treated NHEK showed a redistribution of actin and cytokeratin, and an increase in total cytokeratin (Figure 6e-h), while the cytokeratin 14, a marker for the undifferentiated state of keratinocytes, almost completely disappeared in NAC-treated cells (Figure 6j). Concurrently with the formation of the cornified envelope, actin fibers participated in the enucleation process (green labeling in the inset of Figure 3c). Our results extend those of a previous report on the rearrangement of actin cytoskeleton and on the enhancement of adhesion to plastic or vitrogen substrates after NAC supplementation to human epidermoid carcinoma cells A431. ${ }^{11}$ 

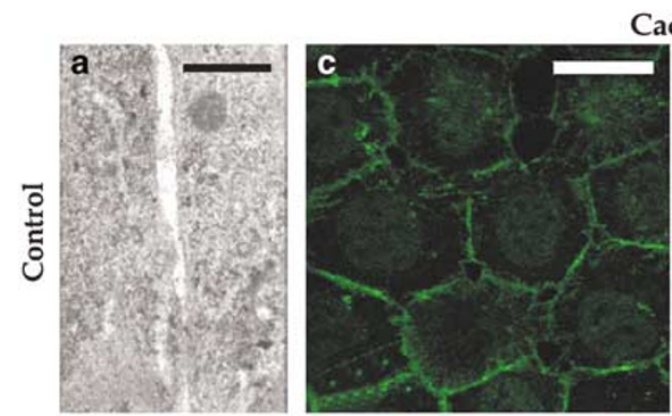

Caco-2
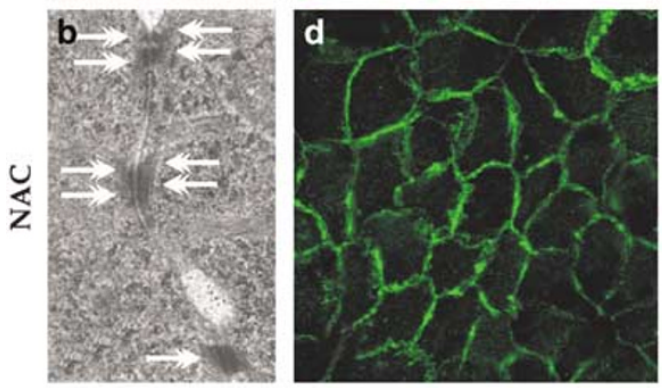

$\beta$-cat
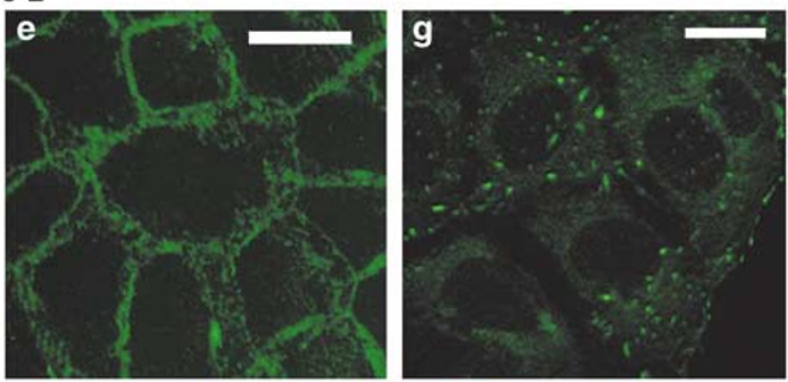

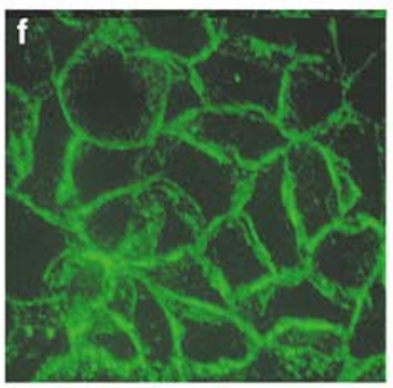

E-cad

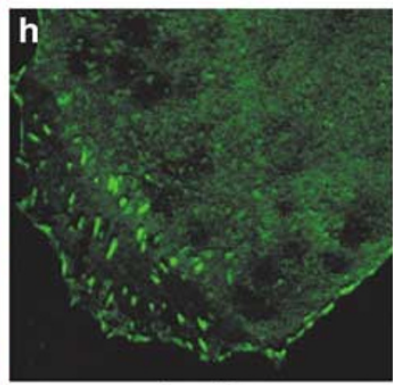

vinculin
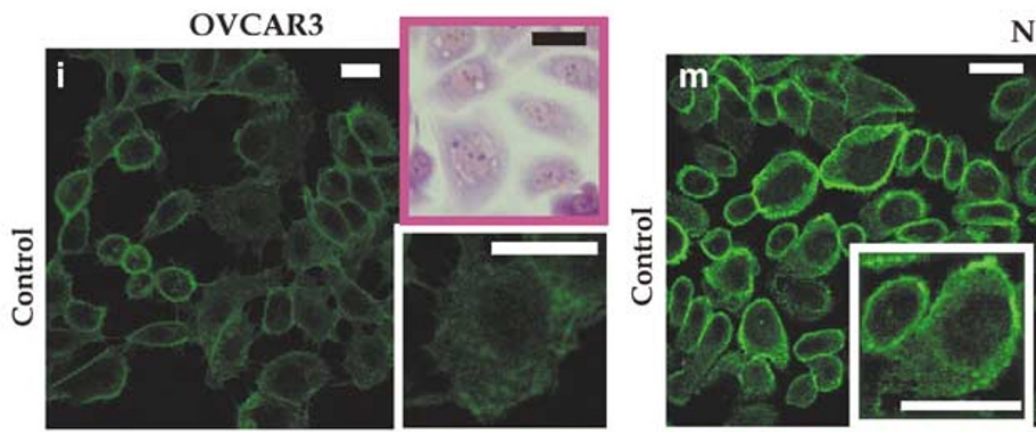

NHEK

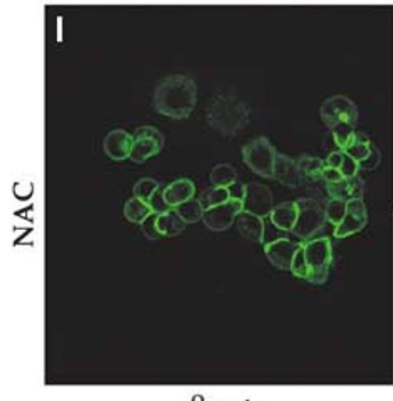

$\beta$-cat

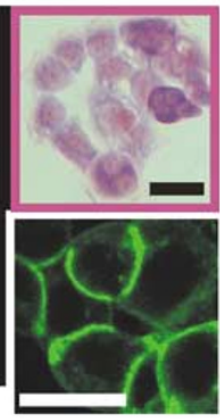

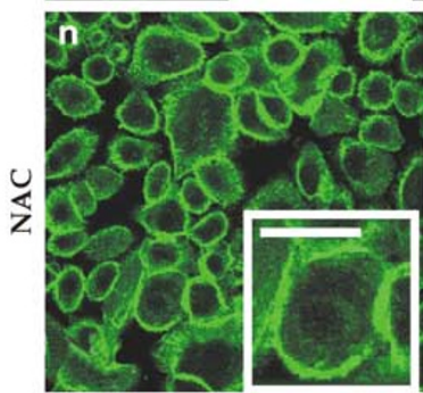

$\beta$-cat
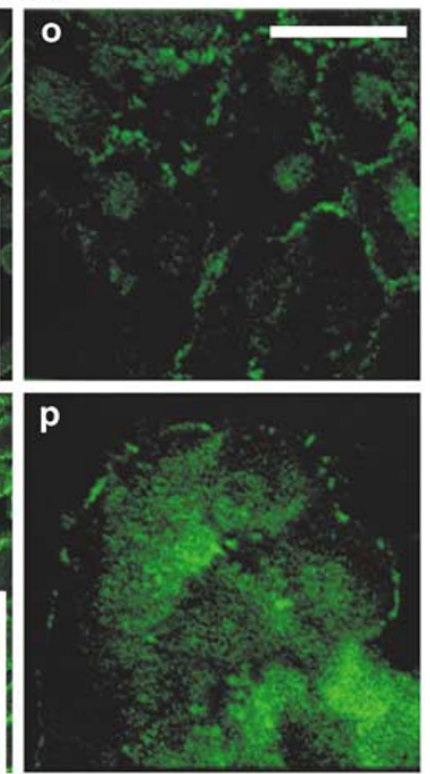

vinculin

Figure 4 Effect of NAC treatment on cell-cell and cell-substratum adhesions. (a-h): Caco-2 cells; (a and $\mathbf{b})$ : transmission electron micrographs of cell-cell contacts in control (a) and in NAC-treated (b) cells. Arrows point to aligned junctions. (c-h): Confocal fluorescence micrographs of $\beta$-catenin (c, d), E-cadherin (e, $\mathbf{f})$ and vinculin $(\mathbf{g}$, $\mathbf{h})$ in controls $(\mathbf{c}, \mathbf{e}, \mathbf{g})$ and in NAC-treated (d, $\mathbf{f}, \mathbf{h})$ cells. (i and I): OVCAR3 cells; confocal fluorescence micrographs of $\beta$-catenin distribution in controls (i) and in NACtreated cells (l); in the lower insets, details at higher magnification of $\beta$-catenin distribution; in the upper insets, optical microscopic images of cells stained with Wright Giemsa. ( $\mathbf{m}-\mathbf{p})$ : NHEK cells; confocal fluorescence micrographs of $\beta$-catenin $(\mathbf{m}, \mathbf{n})$ and vinculin $(\mathbf{0}, \mathbf{p})$ distribution in controls $(\mathbf{m}, \mathbf{0})$ and in NAC-treated $(\mathbf{n}, \mathbf{p})$ cells; in the insets, details at higher magnification. Bars: $500 \mathrm{~nm}$ in (a and $\mathbf{b}) ; 25 \mu \mathrm{m}$ in (c-p)

\section{Real-time RT-PCR analysis - NHEK and Caco-2}

A global gene expression profile of Caco-2 cells and of NHEK after NAC treatment has been performed and will be published elsewhere (Gustafsson AC, Kupershmidt I, Edlundh-Rose E, Parasassi T, Lundeberg T, Bracci-Laudiero
L, Greco G, Krasnowska EK, Romano MC, Serafino A, Lundeberg J. Global gene expression analysis in time series following $N$-Acetyl L-Cysteine induced epithelial differentiation of human normal and cancer cells in vitro, submitted on line to BMC Cancer, Edlundh-Rose E, Kupershmidt I, Gustafsson AC, Parasassi T, Bracci-Laudiero L, Greco G, Krasnowska 
EK, Romano MC, Serafino A, Lundeberg T, Nilsson P, Lundeberg J. Gene expression analysis of human epidermal keratinocytes over time following the addition of the anti-
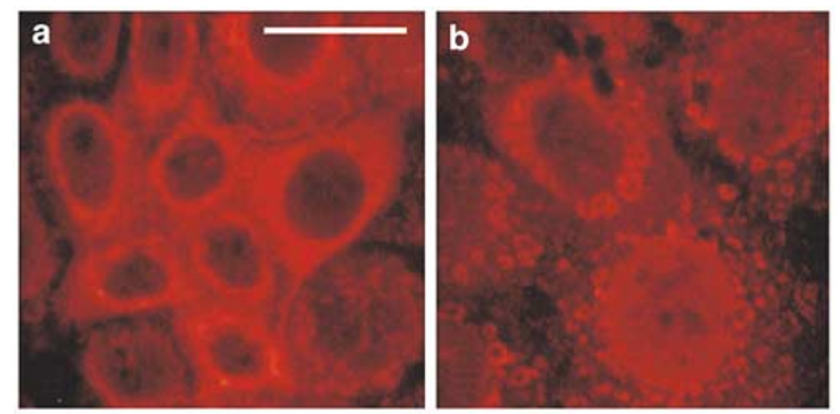

Cytokeratin

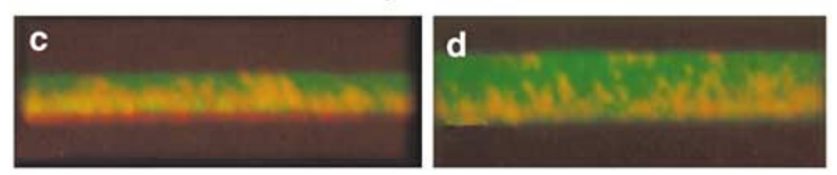

Cytokeratin(green)/Actin(red)
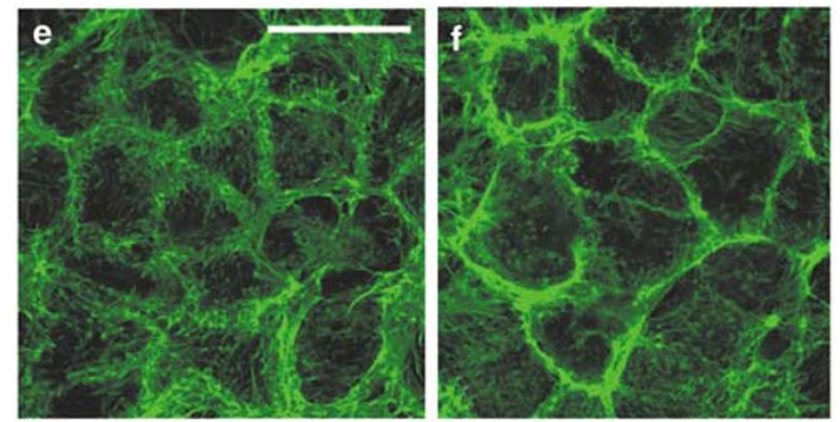

Actin
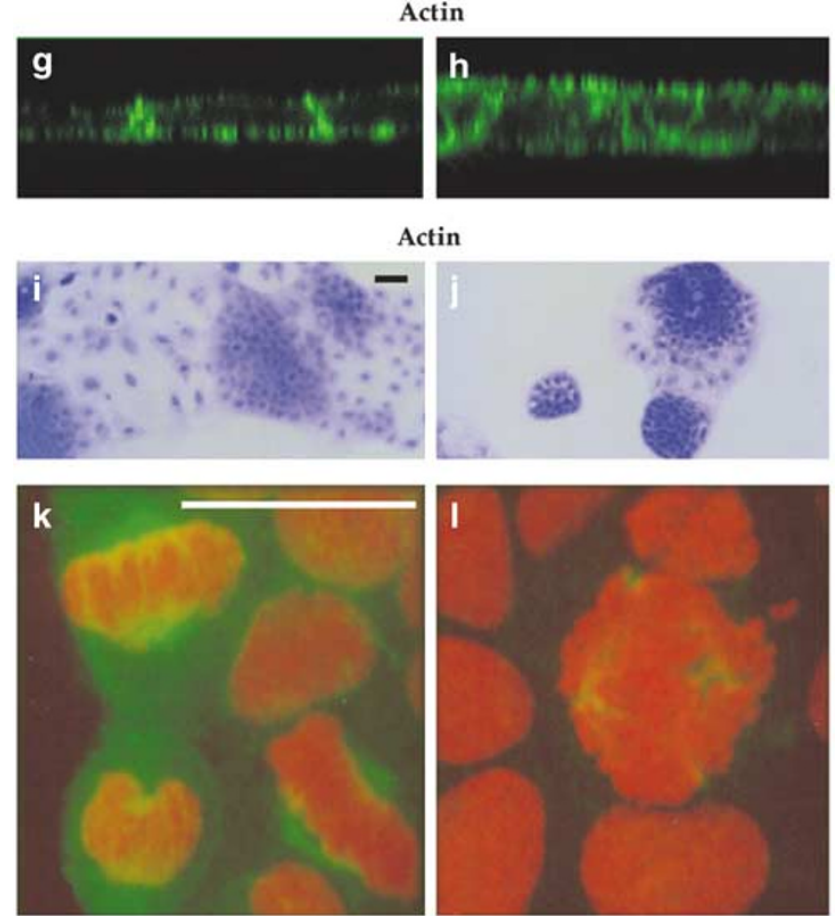

Tubulin/PI oxidant, $\mathrm{N}$-acetyl L-cysteine using spotted cDNA microarrays, submitted to Pathobiology). For the present study, some selected genes were also analyzed using real-time RT-PCR and differential expressions are reported relatively to the untreated control samples (Table 1). In Caco-2 cells, the time sequence of differential gene regulation induced by NAC showed an early (12 h) upregulation of the p53, (HSP27) and $\mathrm{N}$-myc downstream-regulated gene 1 (NDRG1) genes, followed by the upregulation of E-cadherin gene at $24 \mathrm{~h}$. The upregulation of $\mathrm{p} 53$ following NAC treatment is in agreement with a previous report ${ }^{12}$ where microscopic evidence of apoptosis was also reported. Our extensive cytometry investigation excludes the occurrence of apoptosis, reasonably because of the upregulation of the HSP27 gene whose product is reported to prevent apoptosis associated to growth arrest. $^{13-15}$ The upregulation of HSP27 and NDRG1 genes was maintained at $24 \mathrm{~h}$ and up to $48 \mathrm{~h}$, respectively, while the p53 gene expression returned to control levels after $24 \mathrm{~h}$. Interestingly, the COX-2 was downregulated at a late time, 48 h. NHEK cells displayed quite a different behavior than Caco-2 cells, with a delayed upregulation of the p53 and E-cadherin genes, at 24 and $48 \mathrm{~h}$, and a constant upregulation of the HSP27 gene at all times. The NDRG1 and COX-2 genes were not affected by NAC treatment.

\section{Inactivation of c-Src}

Proteins in cell-cell and in cell-matrix adhesions, as well as proteins in the cytoskeleton, are substrates of the nonreceptor proto-oncogene tyrosine kinase $\mathrm{c}-\mathrm{Src} .^{16-18}$ In particular, tyrosine phosphorylation of E-cadherin and $\beta$-catenin induces their disassembly from adhesion junctions. We therefore investigated whether the observed increase in cell-cell and cell-substratum adhesions was dependent on an inhibition of c-Src kinase after NAC treatment. The modulation of c-Src activity is, in turn, mainly achieved by a selective phosphorylation of two tyrosine residues, with phospho-Y419 corresponding to active c-Src and phospho-Y530 corresponding to inactive c-Src. We examined c-Src phosphorylation at the Y419 and Y530 sites, in Caco-2 and OVCAR3 cells lysates, and the results are shown in Figure 7 . In both cell types, after $15 \mathrm{~min}$ from NAC treatment we observed a noticeable decrease in the Y419 phosphorylation, while the Y530 phosphorylation was unaffected. Our results well fit with a mechanism of $\mathrm{c}$-Src inactivation induced by sulfhydryl reduction that decreases Y419 phosphorylation without affecting the phosphorylation of $\mathrm{Y} 530 .^{4-7}$

Figure 5 Effect of NAC treatment on cytoskeleton components of Caco-2 cells. $(\mathbf{a}-\mathbf{h}, \mathbf{k}$ and $\mathbf{l})$ : Confocal fluorescence micrographs of controls (a, c, e, $\mathbf{g}$ and $\mathbf{k})$ and of NAC-treated cells (b, $\mathbf{d}, \mathbf{f}, \mathbf{h}$ and $\mathbf{l})$. Pan-cytokeratin staining in ( $(\mathbf{a}$ and $\mathbf{b}$ ); longitudinal sectioning showing the relative redistribution of actin and cytokeratin along the $x / z$ plane: actin (red)/cytokeratin (green) double staining in (c and $\mathbf{d}$ ). Actin staining in (e-h) with a longitudinal sectioning in ( $\mathbf{g}$ and $\mathbf{h}$ ) showing the distribution of actin microfilaments that, in NAC-treated cells, are mainly located in the upper portion of the cell sustaining the brush border microvilli. ( $\mathbf{k}$ and $\mathbf{I}$ ): Tubulin staining (green) and counterstaining of nuclei with propidium iodide (red). ( $i$ and j): toluidine blue staining of control (i) and of NAC-treated (j) monolayers Bars: $25 \mu \mathrm{m}$ in (a-h, $\mathbf{m}, \mathbf{n}) ; 100 \mu \mathrm{m}$ in (i and $\mathbf{j}$ ) 

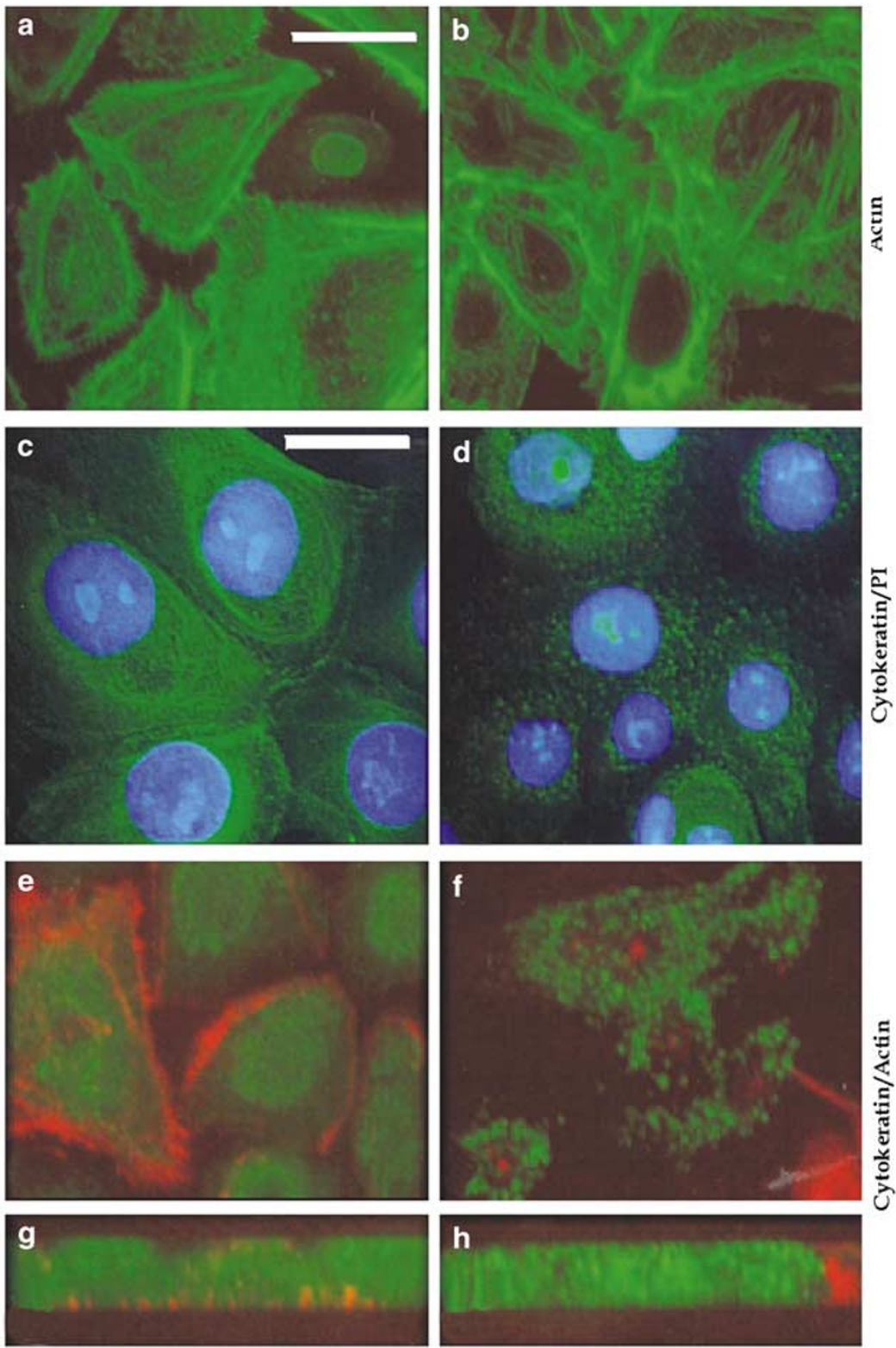

h

魅

لَّ

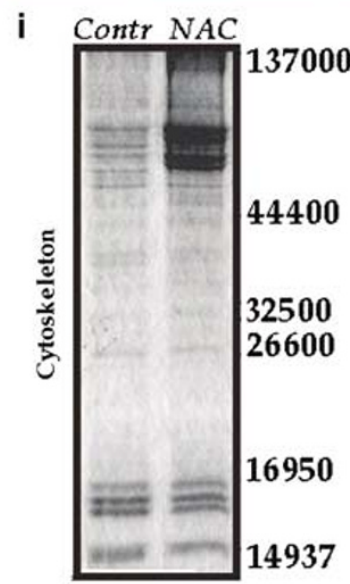

j

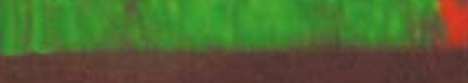

蒈

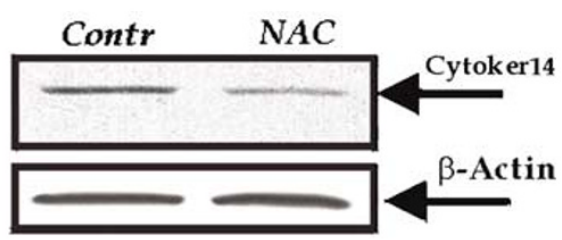

Figure 6 
Table 1 Relative gene expression levels measured by real-time RT-PCR in NAC treated as compared to untreated Caco-2 and NHEK cells

\begin{tabular}{|c|c|c|c|c|c|c|}
\hline \multirow[b]{2}{*}{ Gene } & \multicolumn{3}{|c|}{ Caco-2 } & \multicolumn{3}{|c|}{ NHEK } \\
\hline & $12 \mathrm{~h}$ & $24 \mathrm{~h}$ & $48 h$ & $12 \mathrm{~h}$ & $24 \mathrm{~h}$ & $48 h$ \\
\hline $\begin{array}{l}\text { p53 } \\
\text { Hsp27 } \\
\text { NDRG1 } \\
\text { E-cadherin } \\
\text { COX-2 }\end{array}$ & $\begin{array}{l}\text { Up (4.90) } \\
\text { Up (2.84) } \\
\text { Up (5.40) } \\
\text { Nc (1.33) } \\
\text { Nc (0.91) }\end{array}$ & $\begin{array}{l}\text { Nc (1.51) } \\
\text { Up (2.19) } \\
\text { Up }(6.83) \\
\text { Up }(2.67) \\
\text { Nc }(0.59)\end{array}$ & $\begin{array}{r}\text { Nc (1.47) } \\
\text { Nc }(0.77) \\
\text { Up }(4.56) \\
\text { Nc }(1.08) \\
\text { Down }(0.41)\end{array}$ & $\begin{array}{l}\text { Nc }(1.27) \\
\text { Up }(2.60) \\
\text { Nc }(1.35) \\
\text { Nc }(1.57) \\
\text { Nc }(0.87)\end{array}$ & $\begin{array}{l}\text { Up (2.57) } \\
\text { Up (3.79) } \\
\text { Nc (1.25) } \\
\text { Up (5.22) } \\
\text { Nc (0.69) }\end{array}$ & $\begin{array}{l}\text { Up (2.32) } \\
\text { Up (3.58) } \\
\text { Nc (0.96) } \\
\text { Up (2.63) } \\
\text { Nc (0.61) }\end{array}$ \\
\hline
\end{tabular}

Significant fold change: $0.5<2^{-\Delta \Delta C_{T}}>2$ for down- and upregulated genes, respectively. nc, no change. Numbers in parentheses indicate the measured fold change

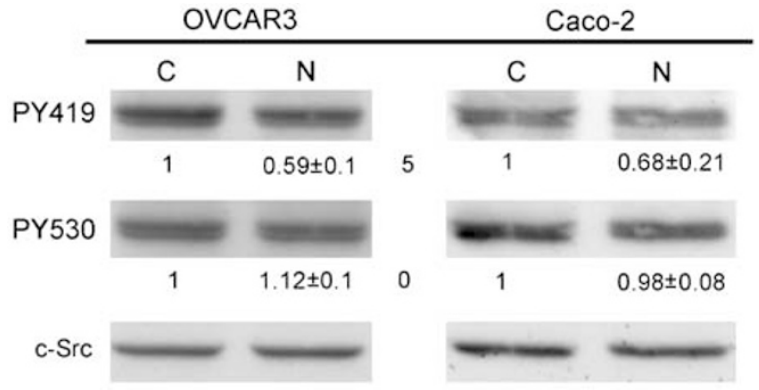

Figure 7 Inactivation of $\mathrm{c}-\mathrm{Src}$ induced by NAC treatment. Proteins from lysate of control cells $(C)$ or of cells treated with NAC (N), 15 min after the treatment, were probed with antiphosphoY419 or Y530 Abs. For the same representative experiment, we also report the bands of the c-Src protein. After antiphosphoY419 probing, membranes were stripped, reprobed with anti-c-Src, stripped again and reprobed with antiphosphoY530. The numbers below bands represent the average intensities of five independent experiments, with S.D. For each experiment, the antiphospho-tyrosine intensity has been normalized to the intensity of its c-Src protein, then each value of a NAC-treated sample has been normalized to its control. Band intensity was read using the Gel-Doc image analyzer system (BioRad, Hercules CA, USA). OVCAR3 cells were treated once with $20 \mathrm{mM} \mathrm{NAC}$, and Caco-2 cells were treated once with $10 \mathrm{mM}$ NAC

\section{Discussion}

The thiol-bearing compound NAC has several experimental and pharmacological uses related to its antioxidant and detoxifying actions. ${ }^{19,20}$ The in vitro differentiating action of NAC reported for the first time in the present work is not related to its radical scavenging properties. Indeed, neither antiproliferative effect nor differentiation were induced by the paradigmatic scavenger Trolox $\mathrm{C}$, supplemented to the cell growth medium at concentrations ranging from 0.1 to $0.5 \mathrm{mM}$. Therefore, NAC action has to be attributed to a modification of protein thiol/disulfide status and to thiol-mediated changes in gene activation. ${ }^{1}$ We observed that also L-cysteine can induce an increase in cell-cell junctions, however using a concentration one order of magnitude higher than that of NAC and therefore with a clearly detectable toxic effect on cells (not shown).
The first result on cell proliferation obtained by sulfhydryl reduction was a dose-dependent and biphasic effect. Both in normal and cancer cells, a low concentration range, below $0.5 \mathrm{mM}$ NAC, stimulated cell proliferation, suggesting a trophic effect. Instead, the mid to high NAC dose range, from 0.5 to $10 \mathrm{mM}$, had a dose-dependent antiproliferative effect in the absence of any variation of cell viability. The inhibition of cell proliferation was also cell type dependent, with a relatively low dose, of $2 \mathrm{mM}$, able to induce a complete block of normal keratinocytes proliferation, while higher doses and, eventually, multiple supplementations were necessary to arrest the colon and the ovary carcinoma cells proliferation. This doseand cell type-dependent antiproliferative - and differentiating - effect of NAC can explain the unsatisfactory results obtained after a 2-year clinical trial on patients with head, neck, or lung cancer, performed with low dosages, that is, $600 \mathrm{mg} / \mathrm{day} .{ }^{21}$ The decreased proliferation of NAC-treated cells is not dependent on apoptosis. In agreement with the generally observed inhibition of apoptosis due to $\mathrm{NAC},{ }^{20}$ our cytometric analysis of NAC-treated Caco-2 and OVCAR3 cells did not show any evidence of apoptosis. In addition, in our confocal microscopy observations, after propidium iodide staining (Figures 5k, I and 6c, d) we never observed fragmented nuclei. Consistently, our gene expression analysis in colon carcinoma cells and in normal keratinocytes showed an early upregulation of both p53, a proliferation suppressor gene, and of HSP27. The HSP27 gene product is reported to prevent apoptosis associated to growth arrest, possibly by binding to cytochrome $c$ and to procaspase-3. ${ }^{13-15}$ The cytometric analysis, instead, suggested that the antiproliferative effect of NAC has to be related to an increase of the cell population in the $\mathrm{G} 1$ phase, finally to a terminal differentiation, as demonstrated by all our other results.

The decrease in proliferation after sulfhydryl reduction resulted in the induction of differentiation in colon and ovary carcinoma cells, and in a 10-fold acceleration of normal keratinocytes differentiation. At a morphological level, in NACtreated cells we showed: (i) a regular polygonal morphology, as opposed to the mesenchymal morphology of proliferating cells; (ii) a de novo formation of the brush border microvillar

Figure 6 Effect of NAC treatment on NHEK cytoskeleton components. (a-h) Confocal fluorescence micrographs of controls $(\mathbf{a}, \mathbf{c}, \mathbf{e}$ and $\mathbf{g})$ and of NAC-treated cells $(\mathbf{b}$, $\mathbf{d}, \mathbf{f}$ and $\mathbf{h}$ ); (a and $\mathbf{b})$ : actin staining; (c and $\mathbf{d})$ : Pan-cytokeratin staining (green) and nuclei (blue) counterstained with propidium iodide; (e-h): actin (red)/cytokeratin (green) double staining; (e and f): transversal sectioning at the level of cell-substratum adhesion site; ( $\mathbf{g}$ and $\mathbf{h})$ : Iongitudinal sectioning showing the relative redistribution of actin and cytokeratin along the $x / z$ plane and the increase in the fluorescence intensity of labeled cytokeratin. Bar: $25 \mu \mathrm{m}$. (i) Electrophoresis of the whole cytoskeleton extracts. (j) Western blotting for the determination of cytokeratin 14 content, and for monitoring the amount of loaded protein by $\beta$-actin, in control and NAC-treated NHEK 
structure in colon carcinoma cells and of the cornified envelope in keratinocytes; (iii) the basal relocation of the nucleus in Caco- 2 cells together with the formation of a robust apical vesicular apparatus; (iv) an overall rearrangement of cytoskeleton to fulfill the requirements of newly formed structures; (v) the appearance of several cell-cell and cellsubstratum junctions; and, finally, (vi) the disappearance of the oncogenic $\beta$-catenin from the nucleus and its only presence at the cell-cell junctions. Taken together, the relocation of $\beta$-catenin at the level of junctions and the increased concentration of E-cadherin represent both markers and inducers of differentiation ${ }^{22-26}$ suggesting the establishment of a positive feedback in the differentiation process. The increase in cell-cell and cell-substratum adhesions identifies a more adhesive and less motile phenotype. Also, an increased cell-substratum adhesion has been indicated as a differentiation marker. ${ }^{27}$

At a molecular level, the upregulation of HSP27 is related to differentiation. ${ }^{13-15}$ Induction of differentiation in Caco-2 cells after NAC treatment was also shown by the early upregulation of the NDRG1 gene, originally identified as a marker of differentiation ${ }^{28-31}$ and usually not found in colon cancer cells. ${ }^{32}$ In tumors, the NDRG1 gene is downregulated while restoration of its expression in neoplastic cells results in growth inhibition and in morphological differentiation of colon cancer cells, accompanied with the increase of differentiation markers such as alkaline phosphatase and E-cadherin. ${ }^{33,34}$ As expected, the NDRG1 gene expression did not change in NHEK cells after NAC treatment. In agreement with the dramatic increase of cell-cell junctions evidenced by immunofluorescence labeling, an upregulation of E-cadherin gene after NAC treatment was evidenced both in Caco-2 and in NHEK. It is worth noticing that in Caco-2 cells the downregulation of COX-2 gene after sulfhydryl reduction well fits the recent efforts in the treatment of colon carcinoma by using nonsteroidal anti-inflammatory drugs (NSAIDs). ${ }^{35,36}$

The genes we analyzed in this work represent a selection from a more extensive gene expression analysis after NAC treatment in colon carcinoma cells and in normal keratinocytes, performed in a time series by the Affymetrix GeneChip $^{\mathrm{TM}}$ Human Genome U95Av2 chip, which contains approximately 12000 previously characterized sequences, and by a spotted cDNA array, comprising approximately 30000 features. On a whole, the obtained results, to be published elsewhere, showed the downregulation of genes involved in proliferation and the upregulation of genes involved in differentiation-related pathways.

Effects on signaling molecules were also observed after sulfhydryl reduction, including the relocation of the oncogenic $\beta$-catenin from the nucleus to the cell-cell junctions. ${ }^{24,25,37}$ Among other functions related to the proliferation/differentiation transition, the nonreceptor tyrosine kinase c-Src has a pivotal role in $\beta$-catenin relocation. ${ }^{38,39}$ Robust in vitro evidences bind the modulation of $c$-Src kinase activity to the redox state of a group of four cysteine residues close to its catalytic site, a key target for a mutually counteracting reversible control operated by oxidizing and reducing agents. $^{4-7}$ The direct involvement of --SH residues has been demonstrated by the use of a nitric oxide generator, known to bind to sulfhydryl residues on proteins, and by reversing this activation, only in vitro, by 2-mercaptoethanol or by dithiothreitol. ${ }^{4,5} \mathrm{c}$-Src was also activated when sulfhydryl cysteine residues were specifically oxidized by mercuric ions. ${ }^{6}$ Mercuric ions have the unique property to react with two adjacent sulfhydryl groups and its action was specifically inhibited by NAC, as a sulfhydryl-donating agent. Which cysteine residues are involved in the redox regulation of c-Src was proven by the use of a series of Src mutants in which cysteines were replaced to alanines. ${ }^{7}$ This modulation of c$\mathrm{Src}$ activity operating though the redox state of - $\mathrm{SH}$ groups implies, for inactivation, a dephosphorylation at the autocatalytic Y419 site, with no effect on the phosphorylation of at the Y530 site. This characteristic phosphorylation pattern is alternative to the well-known regulation operating through phosphatases and kinases acting on the Y530. We hereby demonstrated that the sulfhydryl reductant action of NAC induces the inhibition of c-Src in living cells, yielding the same signature pattern than that obtained in immunoprecipitated c-Src treated with mercaptoethanol or dithiothreitol, ${ }^{4}$ that is, a dephosphorylation of Y419 without affecting Y530. It is worth noticing that in comparison with these other sulfhydryl reductants, NAC is not toxic. Although also protein tyrosine phosphatases should be activated by sulfhydryl reduction, ${ }^{3}$ the lack of Y530 dephosphorylation excludes a role of phosphatases in this NAC-mediated c-Src inactivation. More experiments are in progress to better elucidate this mechanism for c-Src inactivation and to quantitatively determine the oxidized/reduced -SH groups. Indeed, the NAC-mediated inhibition of $\mathrm{c}$-Src deserves a particular attention when considering that: (i) the inherited or acquired deregulation of this kinase has been implicated in the pathogenesis of cancer; (ii) the inhibition of $\mathrm{c}$-Src has been proposed as a promising strategy in anticancer treatment; ${ }^{39}$ and (iii) the recent approval of Imatinib mesylate prompted the investigation of new molecules to inhibit others nonreceptor protein kinases through the design of new drugs able to interfere with the binding of ATP or of the substrate to $\mathrm{C}-\mathrm{Src}$. $^{40,41}$

Together with c-Src inactivation, NAC also downregulates the COX-2 gene in Caco-2 cells. The inhibition of cyclooxygenase-2 represents a target for most recent drug design in cancer therapy. The COX-2 gene is upregulated in several human tumor cells, and antitumor properties of NSAIDs have been demonstrated in epidemiological studies and in experimental animal models. ${ }^{35,42-44}$ Among the evolving family of selective COX-2 inhibitors, some are already in clinical trials for the prevention of colorectal carcinoma and promising results have been reported. ${ }^{44}$

In summary, by treating proliferating normal and cancer cells with NAC we obtained a nonspecific sulfhydryl reduction that shifted the overall cell activity to a differentiated state, through a series of converging mechanisms. The 10-fold acceleration of differentiation observed in primary normal keratinocytes highlights the intervention of sulfhydryl reduction in a physiological switch that can be (partly) conserved after transformation. A further elucidation of involved processes can well be of both physiological and therapeutic interest. Apparently, sulfhydryl reduction can achieve some of the goals of the recent differentiation therapy for cancer treatment. ${ }^{45-47}$ An appropriate drug design would be desirable, to select compounds and delivery methods able to 
minimize adverse alterations of the thiol status in areas external to the targeted regions.

\section{Materials and Methods}

\section{Cell culture and NAC treatment}

The Caco-2 human colon carcinoma cells were seeded at a density of $9 \times 10^{3} \mathrm{cells} / \mathrm{cm}^{2}$, grown in Dulbecco's-modified Eagle minimum essential medium (DMEM, GIBCO Labs, Grand Island, NY, USA), supplemented with $10 \%(\mathrm{v} / \mathrm{v})$ heat-inactivated fetal calf serum (GIBCO Labs), L-glutamine (2 $\mathrm{mM})$, penicillin $(50 \mathrm{IU} / \mathrm{ml})$ and streptomycin $(50 \mu \mathrm{g} / \mathrm{ml})$. OVCAR3 cells at a density of $2 \times 10^{4}$ cells $/ \mathrm{cm}^{2}$, were grown in RPMI 1640 medium with $10 \%$ fetal bovine serum, $10 \mathrm{mM}$ Hepes, $1 \mathrm{mM}$ sodium pyruvate, $4.5 \mathrm{~g} / \mathrm{l}$ glucose, $0.01 \mathrm{mg} / \mathrm{ml}$ insulin, penicillin $(50 \mathrm{lU} / \mathrm{ml})$ and streptomycin $(50 \mu \mathrm{g} / \mathrm{ml})$. Normal human epidermal keratinocytes (NHEK, Cambrex Corp., San Diego, CA, USA), plated at a density of $8 \times 10^{3} / \mathrm{cm}^{2}$, were grown in KGM medium plus KGM Single Quots ( ${ }^{\mathrm{R}}$ Cambrex Corp.). $\mathrm{N}$-acetyl-L-cysteine (NAC, Sigma Chem. Co., St. Louis, MO, USA) stock solution (20 or $100 \mathrm{mM}$ in growth medium), stored at $4^{\circ} \mathrm{C}$ and in the dark, was used within 1 week from preparation and sterilized by filtration before addition to the cell culture. A proper aliquot of NAC stock solution was added to the cell culture $24 \mathrm{~h}$ after seeding. For the proliferation assay (below) the total volume of NAC stock solution never exceeded $20 \%$ of the growth medium.

\section{Cell proliferation and viability assay}

Overnight incorporation of $0.5 \mu \mathrm{Ci} /$ well $\left[{ }^{3} \mathrm{H}\right]$-thymidine (Amersham Biosciences, Freiburg, Germany) by cells plated on 96-wells dishes was determined by liquid scintillation counting in Rach Beta scintillation counter (LKB Wallac 1214 Rack Beta, Bromma, Sweden). Parallel counting of dead cells was performed by Trypan blue $(0.2 \%)$ staining. Cells were seeded at a density of $8 \times 10^{3} / \mathrm{cm}^{2}$ for Caco-2 and NHEK cells and $2 \times 10^{4} / \mathrm{cm}^{2}$ for OVCAR3.

\section{Flow cytometry measurements}

Caco-2 and OVCAR3 cells were treated once or twice, at $24 \mathrm{~h}$ interval, with different NAC concentrations, from 2 to $10 \mathrm{mM}$, as described above. At 3 days after NAC supplementation, cells were fixed in $70 \%$ ethanol and stained with propidium iodide ( $50 \mu \mathrm{g} / \mathrm{ml}$; Sigma Chem. Co.) in PBS containing RNAase A ( $75 \mathrm{kU} / \mathrm{ml}$; Sigma Chem. Co.), and measured by an EPICS 541 (Coulter Hialeah, FL, USA) flow cytometer. DNA histograms were analyzed by a suitable mathematical model $^{10}$ to estimate the percentage of cells in the various phases of the duplication cycle.

\section{Real-time RT-PCR}

Gene-specific real-time PCR primers for six human transcripts (Transferrin receptor: NM_003234, COX-2: NM_000963, n-myc downstream regulated: NM_006096, p53:NM_000546, E-cadherin:NM_004360, hsp27:NM_001540) were designed using the Primer Express software (Applied Biosystems, Foster City, CA, USA). The analysis was performed in triplicate using ds cDNA (diluted 1:50) synthesized from mRNA obtained from Caco-2 cells or NHEK cells grown for 12,24 and $48 \mathrm{~h}$, with or without supplementation of NAC, as template. The total RNA was extracted from cell cultures using Trizol (GIBCO Labs) according to the manufacturers instructions. Thereafter, mRNA was extracted by oligo dT Dynabeads (Dynal, Oslo, Norway) and the quality of mRNA was validated using the Bioanalyzer 2100 (Agilent technologies, Waldbrunn, Germany).
The Transferrin receptor gene was used as internal standard. A PCR mastermixture was prepared using the SYBR ${ }^{\mathbb{R}}$ Green PCR Core Reagents (Applied Biosystems) and aliquoted into microplate wells together with $1 \mu \mathrm{l}$ template and $5 \mathrm{pmol}$ of each primer for a final volume of $25 \mu$ per reaction. The iCycler $\mathrm{QQ}^{\mathrm{TM}}$ Multicolor Real-Time PCR Detection System (Bio-Rad Laboratories, Hercules, CA, USA) was used for PCR and for the detection of fluorescent signal. Standard curves $\left(C_{\top}\right.$ versus log concentration) were generated for each primer pair using duplicate cDNA samples in a series of consecutive five-fold dilutions. Efficiency calculations $\left(E=10^{(-1 / \text { amplificationslope })}-1\right)$ were performed to validate compatibility of investigated genes with the internal control. The compatibility of all pair-wise compared amplification efficiencies were confirmed with a maximal deviation of $10 \%$ (data not shown). The specificity of all individual amplification reactions was confirmed by meltcurve analysis (data not shown). For data evaluation, the comparative threshold cycle $\left(C_{\mathrm{T}}\right)$ method was used, and the level of significance was set to a two-fold relative difference between samples, that is, significant fold change $0.5<2^{-\Delta \Delta C_{\mathrm{T}}}>2$ for down- and upregulated genes, respectively.

\section{Scanning electron microscopy}

Cells grown on coverslips were fixed with $2.5 \%$ glutharaldehyde in $0.1 \mathrm{M}$ Millonig's phosphate buffer (MPB) at $4^{\circ} \mathrm{C}$ for $1 \mathrm{~h}$. After washing in MPB, cells were postfixed with $1 \% \mathrm{OsO}_{4}$ in the same buffer for $1 \mathrm{~h}$ at $4{ }^{\circ} \mathrm{C}$ and dehydrated in increasing acetone concentrations. The specimens were critical-point dried using liquid $\mathrm{CO}_{2}$ and sputter-coated with gold before examination on a Stereoscan 240 scanning electron microscope (Cambridge Instr., Cambridge, UK).

\section{Transmission electron microscopy}

Cells in flask were fixed for $1 \mathrm{~h}$ at $4^{\circ} \mathrm{C}$ with $2.5 \%$ glutharaldehyde in $0.1 \mathrm{M}$ Millonig's phosphate buffer (MPB) containing $2 \%$ sucrose, and postfixed for $1 \mathrm{~h}$ at $4{ }^{\circ} \mathrm{C}$ with $1 \% \mathrm{OsO}_{4}$ in the same buffer. Samples were then scrapped out of flasks, dehydrated in increasing ethanol concentrations and embedded in Spurr epoxy resin (Agar Scientific LTD, Stansted, Essex, UK). Ultrathin sections were stained with uranyl acetate and lead citrate and observed by a Philips CM12 transmission electron microscope operating at $80 \mathrm{kV}$.

\section{Optical microscopy}

Treated and untreated OVCAR3 or Caco-2 cells, grown on coverslips, were stained with Wright Giemsa or toluidine blue, respectively, and observed by optical microscopy.

\section{Immunofluorescence labeling and confocal microscopy observations}

Cells grown on coverslips were fixed with $4 \%$ paraformaldehyde for $10 \mathrm{~min}$ and permeabilized with $0.2 \%$ Triton-X 100 in PBS for 5 min. Indirect immunofluorescence staining was performed using the following primary antibodies: (i) $\mathrm{mAb}$ to human vinculin (Sigma Chem. Co.); (ii) $\mathrm{mAb}$ to E-cadherin (Sigma Chem. Co.); (iii) mAb to $\beta$-catenin (Transduction Labs, Lexington, KY). Primary antibody detection was obtained by reaction with fluorescein (FITC)-conjugated IgG (Sigma Chemical Co.). Actin microfilaments were stained with FITC-conjugated phalloidin (Sigma Chem. Co.), cytokeratin was stained by mAbs to FITC-labeled Pan-cytokeratin and 
microtubules were stained by rabbit polyclonal antibody raised against chicken tubulin plus FITC IgG. Cell nuclei were stained with $2 \mu \mathrm{g} / \mathrm{ml}$ propidium iodide (Sigma Chem. Co.) in the presence of $0.1 \mathrm{mg} / \mathrm{ml}$ RNAase (Sigma Chem. Co.). For Golgi apparatus and endoplasmic reticulum staining, cells were incubated with TRITC-conjugated wheat germ agglutinin (WGA-TRITC; Sigma Chem. Co.) for $1 \mathrm{~h}$ at room temperature.

Fluorescently labeled samples were imaged by a confocal LEICA TCS 4D microscope (Leica, Heidelberg, Germany) equipped with an argon/ krypton laser. Confocal sections were taken at 0.5-1 $\mu \mathrm{m}$ intervals. The excitation and emission wavelengths were 488 and $510 \mathrm{~nm}$, respectively, for FITC-labeling, and 568 and $590 \mathrm{~nm}$, respectively, for propidium iodide and TRITC-labeling. The NIH ImageJ software was used to calculate the integrated fluorescence intensity of interest, after subtracting a constant background.

\section{Whole cytoskeleton extraction}

NHEK were washed twice with PBS containing $1 \mathrm{mM} \mathrm{Ca}^{2+}$ and $\mathrm{Mg}^{2+}$, and incubated for $20 \mathrm{~min}$ at $4^{\circ} \mathrm{C}$ with the extraction buffer $(50 \mathrm{mM} \mathrm{Tris} / \mathrm{HCl}$, pH 7.5, $40 \mathrm{mM} \mathrm{KCl,} 5 \mathrm{mM}$ EGTA, $5 \mathrm{mM} \mathrm{MgCl}$, 1\% Triton X-100, $1 \mathrm{mM}$ PMSF, $40 \mu \mathrm{g} / \mathrm{ml}$ aprotinin, $2 \mathrm{mM}$ benzamidine). Cells were then scraped, centrifuged at $4000 \times g$ at $4^{\circ} \mathrm{C}$ for $20 \mathrm{~min}$. The pellet was washed twice with the extraction buffer and resuspended in $8 \mathrm{M}$ urea/1\% SDS. Samples of $6 \mu \mathrm{g}$ protein were used for PAGE on $15 \%$ slab gel under nonreducing conditions. For immunoblotting, proteins from SDS-PAGE were transferred into nitrocellulose filter (Amersham Biosciences), using 4\% milk protein in Tris-buffered saline (TBS: $25 \mathrm{mM}$ Tris, pH 7.5, 0.5 M NaCl), then exposed to the mouse anticytokeratin peptide 14 (Sigma Chem. Co.). After incubation for $1 \mathrm{~h}$ with sheep anti-mouse biotinylated IgG (Amersham Biosciences), the blot was transferred to a solution of streptavidin conjugated with horseradish peroxidase (Amersham Biosciences), washed three times with TBS and developed by the Bio-Rad system. The blot was simultaneously incubated with anti- $\beta$-actin antibody to monitor the amount of protein.

\section{Immunoblotting}

Cells were washed twice with ice-cold PBS containing $1 \mathrm{mM} \mathrm{Na}_{3} \mathrm{VO}_{4}$ and lysed with RIPA buffer $(20 \mathrm{mM}$ Tris- $\mathrm{HCl}$ pH 7.4, $1 \%$ Triton X-100, $150 \mathrm{mM} \mathrm{NaCl}, 5 \mathrm{mM} \mathrm{MgCl}_{2}, 0.5 \%$ sodium deoxycolate, $0.1 \%$ SDS, $50 \mathrm{mM}$ $\mathrm{NaF}$ and $1 \%$ protease-phosphatase inhibitor cocktail (Sigma Chem. Co.)) for $20 \mathrm{~min}$ at $4^{\circ} \mathrm{C}$. The lysate was centrifuged $10 \mathrm{~min}$ at $1000 \times \mathrm{g}$ at $4^{\circ} \mathrm{C}$ and protein concentration was determined (Bradford assay, Bio-Rad Labs.). Proteins were resolved on SDS $10 \%$ polyacrylamide and transferred to a nitrocellulose membrane. The membrane was incubated with anti-Src mouse monoclonal antibody (Upstate Biotechnology, Lake Placid, NY, USA) and with anti-Src phosphospecific Y419 and Y530 rabbit polyclonal antibodies (Calbiochem, Cambridge, MA, USA; where human Y419 and Y530 correspond to the Y416 and Y527 chicken c-Src numbering, respectively) for $1 \mathrm{~h}$ at room temperature. Proteins were then probed with the appropriate horseradish peroxidase-conjugated antibodies for $1 \mathrm{~h}$ at room temperature and visualized by ECL-Western blotting detection reagents (Amersham Biosciences).

\section{Acknowledgements}

We thank Giuseppe Starace for performing the flow cytometry measurements and data analysis. We also thank Graziella Costa for her excellent technical assistance. This work was supported by Nactilus $A B$,
Malmö, Sweden (TP, LB-L, GG, EKK, MCR) and by the Swedish Cancer Foundation (ACG, JL).

\section{References}

1. Deneke SM (2000) Thiol-based antioxidants. Curr. Top. Cell Regul. 36: 151180

2. Cho SH, Lee CH, Ahn Y, Kim H, Kim H, Ahn CY, Yang KS and Lee SR (2004) Redox regulation of PTEN and protein tyrosine phosphatases in $\mathrm{H}(2) \mathrm{O}(2)$ mediated cell signaling. FEBS Lett. 560: 7-13

3. Chiarugi P, Fiaschi T, Taddei ML, Talini D, Giannoni E, Raugei G and Ramponi G (2001) Two vicinal cysteines confer a peculiar redox regulation to low molecular weight protein tyrosine phosphatase in response to platelet-derived growth factor receptor stimulation. J. Biol. Chem. 276: 33478-33487

4. Akhand AA, Pu M, Senga T, Kato M, Suzuki H, Miyata T, Hamaguchi M and Nakashima I (1999) Nitric oxide controls Src kinase activity through a sulfhydryl group modification-mediated Tyr-527-independent and Tyr-416-linked mechanism. J. Biol. Chem. 274: 25821-25826

5. Minetti M, Mallozzi C and Di Stasi AM (2002) Peroxynitrite activates kinases of the src family and upregulates tyrosine phosphorylation signaling. Free Radic. Biol. Med. 33: 744-754

6. Pu M, Akhand AA, Kato M, Hamaguchi M, Koike T, Iwata H, Sabe H, Suzuki H and Nakashima I (1996) Evidence of a novel redox-linked activation mechanism for the Src kinase which is independent of tyrosine 527mediated regulation. Oncogene 13: 2615-2622

7. Oo ML, Senga $T$, Thant AA, Amin AR, Huang $P$, Mon NN and Hamaguchi $M$ (2003) Cysteine residues in the C-terminal lobe of Src: their role in the suppression of the Src kinase. Oncogene 22: 1411-1417

8. Sun Y and Oberley LW (1996) Redox regulation of transcriptional activators. Free Radic. Biol. Med. 21: 335-348

9. Sen CK and Packer L (1996) Antioxidant and redox regulation of gene transcription. FASEB J. 10: 709-720

10. Bertuzzi A, Gandolfi A, Germani A, Spano M, Starace G and Vitelli R (1984) Analysis of DNA synthesis rate of cultured cells from flow cytometric data. Cytometry 5: 619-628

11. Rivabene R, Viora M, Matarrese P, Rainaldi G, D'Ambrosio A and Malorni W (1995) $\mathrm{N}$-acetyl-cysteine enhances cell adhesion properties of epithelial and lymphoid cells. Cell Biol. Int. 19: 681-686

12. Liu M, Pelling JC, Ju J, Chu E and Brash DE (1998) Antioxidant action via p53mediated apoptosis. Cancer Res. 58: 1723-1729

13. Concannon CG, Gorman AM and Samali A (2003) On the role of Hsp27 in regulating apoptosis. Apoptosis 8: 61-70

14. Charette SJ, Lavoie JN, Lambert $\mathrm{H}$ and Landry J (2000) Inhibition of Daxxmediated apoptosis by heat shock protein 27. Mol. Cell. Biol. 20: 7602-7612

15. Mehlen $P$, Mehlen A, Godet J and Arrigo AP (1997) hsp27 as a switch between differentiation and apoptosis in murine embryonic stem cells. J. Biol. Chem. 272: 31657-31665

16. Thomas SM, Soriano $P$ and Imamoto $A$ (1995) Specific and redundant roles of Src and Fyn in organizing the cytoskeleton. Nature 376: 267-271

17. Bourguignon LYW, Zhu H, Shao L and Chen Y-W (2001) CD44 interaction with $\mathrm{c}$-Src kinase promotes cortactin-mediated cytoskeleton function and hyaluronic acid-dependent ovarian tumor cell migration. J. Biol. Chem. 276: 7327-7336

18. Faccio R, Novack DV, Zallone A, Ross FP and Teitelbaum SL (2003) Dynamic changes in the osteoclast cytoskeleton in response to growth factors and cell attachment are controlled by $\beta 3$ integrin. J. Cell Biol. 162: 499-509

19. De Flora S, Izzotti A, D'Agostini F and Balansky RM (2001) Mechanisms of $\mathrm{N}$-acetylcysteine in the prevention of DNA damage and cancer, with special reference to smoking-related end-points. Carcinogenesis 22: 999-1013

20. Zafarullah M, Lia WQ, Sylvestera J and Ahmadb M (2003) Molecular mechanisms of $\mathrm{N}$-acetylcysteine actions. Cell Mol. Life Sci. 60: 6-20

21. van Zandwijk N, Dalesio O, Pastorino U, de Vries N and van Tinteren $\mathrm{H}(2000)$ EUROSCAN, a randomized trial of vitamin $\mathrm{A}$ and $\mathrm{N}$-acetylcysteine in patients with head and neck cancer or lung cancer. For the European Organization for Research and Treatment of Cancer Head and Neck and Lung Cancer Cooperative Groups. J. Natl. Cancer Inst. 92: 977-986

22. Yap AS and Kovacs EM (2003) Direct cadherin-activated cell signaling: a view from the plasma membrane. J. Cell Biol. 160: 11-16 
23. Caron E (2003) Rac signaling: a radical view. Nat. Cell Biol. 5: 185-187

24. Conacci-Sorrell M, Zhurinsky J and Ben-Ze'ev A (2002) The cadherin-catenin adhesion system in signaling and cancer. J. Clin. Invest. 109: 987-991

25. Henderson BR and Fagotto $\mathrm{F}(2002)$ The ins and outs of APC and $\beta$-catenin nuclear transport. EMBO Rep. 3: 834-839

26. Giles $\mathrm{RH}$, van Es JH and Clevers $\mathrm{H}$ (2003) Caught up in a Wnt storm: Wnt signaling in cancer. Biochim. Biophys. Acta. 1653: 1-24

27. Murphy-Ullrich JE (2001) The de-adhesive activity of matricellular proteins: is intermediate cell adhesion an adaptive state? J. Clin. Invest. 107: 785-790

28. Hirvonen H, Makela TP, Sandberg M, Kalimo H, Vuorio E and Alitalo K (1990) Expression of the myc proto-oncogens in developing human fetal brain. Oncogene 5: 1787-1797

29. Kokame K, Kato H and Miyata T (1996) Homocysteine-respondent genes in vascular endothelial cells identified by differential display analysis. GRP78/BiP and novel genes. J. Biol. Chem. 271: 29659-29665

30. van Belzen N, Dinjens WN, Diesveld MP, Groen NA, van der Made AC Nozawa Y, Vlietstra R, Trapman J and Bosman FT (1997) A novel gene which is up-regulated during colon epithelial cell differentiation and down-regulated in colorectal neoplasms. Lab. Invest. 77: 85-92

31. Steidl U, Kronenwett R, Rohr UP, Fenk R, Kliszewski S, Maercker C, Neubert P, Aivado M, Koch J, Modlich O, Bojar H, Gattermann N and Haas R (2002) Gene expression profiling identifies significant differences between the molecular phenotypes of bone marrow-derived and circulating human CD34+ hematopoietic stem cells. Blood 99: 2037-2044

32. Van Seuningen I, Perrais M, Pigny P, Porchet N and Aubert JP (2000) Sequence of the $5^{\prime}$-flanking region and promoter activity of the human mucin gene MUC5B in different phenotypes of colon cancer cells. Biochem. J. 348: 675-686

33. Guan RG, Ford HL, Fu Y, Li Y, Shaw LM and Pardee AB (2000) Drg-1 as a differentiation-related, putative metastatic suppressor gene in human colon cancer. Cancer Res. 60: 749-755

34. Kurdistani SK, Arizti P, Reimer CL, Sugrue MM, Aaronson SA and Lee SW (1998) Inhibition of tumor cell growth by RTP/rit42 and its responsiveness to p53 and DNA damage. Cancer Res. 58: 4439-4444
35. Sinicrope FA and Gill S (2004) Role of cyclooxygenase-2 in colorectal cancer. Cancer Metastasis Rev. 23: 63-75

36. Maier TJ, Schilling K, Schmidt R, Geisslinger G and Grosch S (2004) Cyclooxygenase-2 (COX-2)-dependent and -independent anticarcinogenic effects of celecoxib in human colon carcinoma cells. Biochem. Pharmacol. 67: 1469-1478

37. Van Aken E, De Wever $O$ and Correia de Rocha AS (2001) Defective E-cadherin/catenin complexes in human cancer. Virchows Arch. 439: 725-751

38. Frame MC (2002) Src in cancer: deregulation and consequences for cell behaviour. Biochim. Biophys. Acta. 1602: 114-130

39. Yeatman TJ (2004) A renaissance for Src. Nat. Rev. Cancer 4: 470-480

40. Tsygankov AY and Shore SK (2004) Src: regulation, role in human carcinogenesis and pharmacological inhibitors. Curr. Pharm. Des. 10: $1745-1756$

41. Warmuth M, Damoiseaux R, Liu Y, Fabbro D and Gray N (2003) SRC family kinases: potential targets for the treatment of human cancer and leukemia. Curr. Pharm. Des. 9: 2043-2059

42. Koehne $\mathrm{CH}$ and Dubois RN (2004) COX-2 inhibition and colorectal cancer. Semin. Oncol. 31: 12-21

43. Gately S and Li WW (2004) Multiple roles of COX-2 in tumor angiogenesis: a target for antiangiogenic therapy. Semin. Oncol. 31: 2-11

44. Chu AJ, Chou TH and Chen BD (2004) Prevention of colorectal cancer using COX-2 inhibitors: basic science and clinical applications. Front. Biosci. 9 : 2697-2713

45. Sell S (2004) Stem cell origin of cancer and differentiation therapy. Crit. Rev. Oncol. Hematol. 51: 1-28

46. Chen F, Wang $Q$, Wang X and Studzinski GP (2004) Up-regulation of Egr1 by 1,25-dihydroxyvitamin D3 contributes to increased expression of p35 activator of cyclin-dependent kinase 5 and consequent onset of the terminal phase of HL60 cell differentiation. Cancer Res. 64: 5425-5433

47. Eckert RL, Crish JF, Efimova T and Balasubramanian S (2004) Antioxidants regulate normal human keratinocyte differentiation. Biochem. Pharmacol. 68: $1125-1131$ 